\title{
Kearifan Lokal Sebagai Jembatan Berteologi dan Berbudaya
}

\author{
Frets Keriapy \\ fretskeriapy1106@gmail.com \\ Sekolah Tinggi Agama Kristen PESAT
}

\begin{abstract}
Indonesia is a nation that has so many differences. Difference in religions, ethnicities, languages, rituals, symbols, and so on. This diversity makes Indonesia a pluralistic nation. Accepting differences is a part of the basic state that is written and also fought by the heroes in the past. Furthermore, culture is the identity of a person or group. Eliminating culture, as well as removing identity. This is a serious problem that could threaten the unity of the Republic of Indonesia once it is examined carefully. In this diversity, how should theology be applied? In this article, the author will explain how local wisdom in Maluku, which is "Pela Gandong" will help us to love one another. The two highest laws in Christianity are loving God and also loving others. Theologizing by using local wisdom is a theology that does not discredit culture. Finally, be proud of Indonesia. Be proud of diversity. Be proud of Pancasila!
\end{abstract}

Keywords: Local wisdom, Theologizing, Identity, Culture and Diversity, Religion, Ideology

\section{Pendahuluan}

Kita sering sekali mendengar pernyataan yang sering dikumandangkan bahwa manusia adalah makhluk sosial. Pernyataan ini pertama kali muncul dari Aristoteles, seorang filsuf Yunani yang manggaungkan Zoon Politicon, yang artinya manusia adalah makhluk yang selalu ingin bergaul dan berkumpul dengan orang lain. Hal senada pun dikatakan oleh Eka Darmaputera bahwa dimensi sosial ini tidak hanya sekedar merupakan sebuah lampiran tambahan pada hakikat manusia, sekedar tujuan-tujuan praktis melainkan ia merupakan sebuah inheren pada hakikat manusia itu sendiri. ${ }^{1}$ Selanjutnya sebagaimana yang dikatakan oleh Theodore M Steemen yang dikutip Eka Darmaputera dalam bukunya mangatakan bahwa individu-individu mempunyai kepentingan terhadap masyarakat dan keberesannya, dan oleh karena itu, secara pribadi terdorong untuk mengambil bagian dalam proses sosial. ${ }^{2}$

Di samping manusia adalah makhluk sosial, saya ingin menambahkan bahwa manusia adalah makhluk berbudaya. Setiap manusia di muka bumi ini lahir dan berada dalam budaya tertentu. Budaya tersebut tidak dapat lepas begitu saja dari diri manusia dan akan selalu

\footnotetext{
${ }^{1}$ Eka Darmaputera, Pancasila Identitas dan Modernitas, (Jakarta: 2017), hal. 8

${ }^{2}$ Ibid.
} 
terbawa kemanapun ia pergi. Pada akhirnya, budaya menjadi identitas yang tidak akan pernah terelakkan dari diri manusia. Menurut Hog dan Abram sebagaimana yang dikutip oleh Elifax Tomix Maspateila identitas merupakan konsep masyarakat mengenai siapa mereka, seperti apa mereka, dan bagaimana hubungan mereka dengan orang lain ${ }^{3}$. Identitas sangat memengaruhi cara kita membangun relasi dan berkomunikasi dengan orang lain. Orang yang berada di Indonesia Timur tentu memiliki cara berbicara yang berbeda dengan orang Jawa. Orang Timur terkenal dengan volume suara yang keras dan kadang-kadang terdengar sangat pedas di telinga. Berbeda dengan orang Jawa yang gaya berbicara halus nan lembut. Selanjutnya Elifax membedakan identitas dalam dua kategori, yakni kategori sosial dan individual self-respect. Kategori sosial merupakan gambaran utuh mengenai diri seseorang dan juga komunitas. Sedangkan individual self-respect sangat bersentuhan dengan nilai-nilai etika yang diyakini oleh pribadi seseorang yang mengenakannya. Di situlah tata etika dalam berhubungan dengan orang lain diatur. ${ }^{4}$

Jika demikian, apa jadinya jika manusia melepaskan budaya yang dimilikinya sejak lahir? Tentu dengan melepaskan budaya, sama halnya dengan berusaha menghilangkan identitas. Sama halnya dengan nama yang merupakan identitas seseorang, budaya pun merupakan identitas. C.S. Song mengatakan bahwa nama bukanlah sebuah konsep kosong. Ia adalah sebuah substantif yang tentunya memiliki hakekat. ${ }^{5}$ Sehingga dengan mencabut nama seseorang, maka sama halnya kita sedang mencabut apa yang menjadi hakikat dalam diri orang tersebut. Demikian juga dengan budaya, orang lain akan mengenal dari mana kita berasal (identitas diri) dengan melihat budaya yang melekat dalam diri kita. Selain itu, budaya menjadi salah satu kendaraan bagi seseorang untuk bergerak mengaktualisasikan diri sehingga kebutuhan tertinggi manusia dapat terpenuhi seperti teori ditemukan oleh Abram Maslow dalam bukunya Hierarchy of needs.

Indonesia merupakan negara multikultur, multi bahasa, dan multi agama. Hal ini menyebabkan budaya dalam satu daerah berbeda dengan budaya yang berada pada daerah lain. Beragam bahasapun dapat dijumpai di seluruh penjuru Indonesia. Agama yang dianut juga berbeda-beda, baik agama yang diakui negara (Islam, Kristen Protestan, Kristen Katolik, Hindu, Budha, dan Konghuchu) maupun agama-agama suku yang belum diakui negara. Apabila kita kembali pada sejarah masa pra kemerdekaan dan masa awal kemerdekaan, kita

\footnotetext{
${ }^{3}$ Izak Lattu, et.al, (Ed). Sosiologi Agama Pilihan Berteologi di Indonesia, (Salatiga: 2016), hal. 315. ${ }^{4}$ Ibid.

${ }^{5}$ C.S. Song, Sebutkanlah Nama-Nama Kami Teologi Cerita Dari Perspektif Asia, ( Jakarta: 2001), hal.
} 
akan menemukan bahwa Indonesia lahir dari perbedaan. Kemerdekaan Indonesia tidak hanya diusahakan oleh orang Jawa saja atau orang Ambon saja. Kemerdekaan Indonesia justru diusahakan oleh semua kalangan. Dalam sejarah awal kemerdekaan, kita dapat menjumpai orang-orang non muslim dan non Jawa yang juga ikut mengambil bagian dalam susunan kabinet. Sebut saja Todung Sutan Gunung Mulia, pria Kristen asal Sumatra Utara yang pada saat itu menjabat sebagai menteri pendidikan menggantikan Ki Hajar Dewantara, serta Johanes Leimena, pria Kristen asal Ambon yang menjabat sebagai perdana menteri, menteri kesehatan, bahkan berkali-kali menjadi pelaksana tugas presiden. ${ }^{6}$

Perbedaan yang dimiliki Indonesia ternyata juga menjadi sebuah kekuatan yang kemudian menghapus tujuh kata dalam Piagam Jakarta, yaitu ketuhanan dengan kewajiban menjalankan syariat Islam bagi pemeluk-pemeluknya. Banyak pihak khususnya dari Indonesia Timur memberikan protes karena isi dari piagam Jakarta yang dibentuk pada 22 Juni 1945 tersebut. Pihak-pihak dari Indonesia Timur menyampaikan keberatan atas pemberlakuan ini karena Indonesia hendak dijadikan negara Islam. Bentuk protes yang diberikan adalah Indonesia Timur memberikan ancaman untuk tidak bergabung dengan Indonesia apabila hukum syariat Islam diberlakukan. Akhirnya tujuh kata dalam Piagam Jakarta direvisi menjadi Ketuhanan yang Maha Esa dan ditempatkan pada sila pertama. ${ }^{7}$ Hal ini menjadi sejarah yang penting bagi Indonesia agar setiap lapisan masyarakat mengerti akan dasar berdirinya bangsa Indonesia. Bahwa Indonesia tidak pernah lahir dari satu ideologi tertentu. Indonesia tidak pernah lahir dari satu kepercayaan tertentu. Indonesia tidak pernah lahir dari satu agama tertentu. Menjadi bagian dari negara Indonesia, berarti menjadi bagian dari keberagaman yang ada. Menghormati dan menghargai akan keberbedaan yang ada merupakan identitas dari bangsa Indonesia. Memaksakan seseorang menjadi pengikut agama/kepercayaan/ideologi tertentu, sama halnya dengan mengubah atau bahkan mencabut identitas seseorang dan bahkan bangsa.

Perjalanan Indonesia sebagai suatu bangsa majemuk tentu tidak semulus jalan tol. Banyak lika-liku yang harus juga dihadapi sebagai bangsa besar nan majemuk. Salah satunya adalah tindakan diskriminasi yang dilakukan suku tertentu kepada suku yang lain atau agama tertentu kepada agama yang lain. Selain itu kekristenan yang semakin kebarat-baratan dan keislaman yang semakin kearab-araban. Budaya Indonesia sesungguhnya semakin tenggelam

\footnotetext{
${ }^{6}$ Andar Ismail. Selamat Mengindonesia, (Jakarta : 2019), hal. 14 -18

${ }^{7}$ John Campbell-Nelson, et.al. (Ed). Teologi Politik Panggilan Gereja di Bidang Politik Pascaorde Baru, (Makasar: 2013), hal. 20-21.
} 
dalam ajang adu pamer siapa yang lebih kuat, siapa yang lebih benar. Sangat disayangkan jika hal ini terus terjadi, karena jika teologi atau agama berusaha untuk menghilangkan budaya, maka teologi/agama sedang merampas atau bahkan mencabut identitas seseorang yang sejak lahir tertanam dalam dirinya. Hal ini adalah bagian dari yang bisa saya sebut dengan penindasan!

Tulisan ini lahir dari kegelisahan penulis akan begitu maraknya konflik yang terjadi karena perbedaan ideologi atau kepercayaan atau agama. Kegelisahan ini kemudian membuat penulis ingin menyumbangkan buah pikiran tentang bagaimana menggunakan kearifan lokal sebagai jembatan untuk berteologi dan berbudaya. Diharapkan tulisan ini dapat menjadi acuan bagi pembaca untuk tidak lagi menjadikan perbedaan sebagai alasan untuk tidak menganggap orang lain bukan bagian dari sesama kita, melainkan mengasihi orang lain dalam perbedaan sebagaimana yang katakan oleh Alkitab bahwa, kasihilah sesamamu manusia seperti dirimu sendiri. Bahkan di ayat yang lain, Yesus mengatakan kasihilah musuhmu (Matius 5:43 dan Matius 22:39). Perintah ini menjadi perintah yang begitu penting bagi setiap orang khususnya orang Kristen di dalam memaknai sesama manusia.

\section{Berteologi Sekaligus Berbudaya dan Bernegara}

Teologi merupakan ilmu yang mempelajari akan sesuatu yang ilahi yang sering kita sebut dengan TUHAN. Istilah teologi berasal dari akar kata dua istilah bahasa Yunani, theos dan logos. Theos berarti 'Allah' atau 'ilah'; logos berarti 'perkataan/firman/wacana'. Jadi, teologi adalah wacana (ilmiah) mengenal Allah atau ilah-ilah. ${ }^{8}$ Dengan definisi yang begitu sederhana ini seakan-akan manusia dapat mengenal Allah secara detail/ sempurna apabila manusia tekun/ serius mempelajari teologi. Manusia yang sangat terbatas tentu tidak akan pernah bisa mengenal Allah yang tidak terbatas secara sempurna. Setiap ilmu tentu memiliki kekurangan atau keterbatasan karena dibuat oleh otak manusia yang terbatas, termasuk teologi. Menurut Barth, manusia tidak dapat mengenal Allah melalui perasaan atau melalui akal. $^{9}$

Keberdosaan manusia menjadikan manusia terbatas mengenal Allah. Lalu yang menjadi pertanyaan adalah apa yang menjadi tujuan kita mempelajari teologi? Seberapa penting teologi dalam kehidupan manusia di tengah zaman modern yang masif berkembang?

\footnotetext{
${ }^{8}$ B.F. Drewes dan Julianus Mojau, Apa itu Teologi? Pengantar Ke Dalam Ilmu teologi, (Jakarta: 2012), hal. 16.

${ }^{9}$ Ibid. hal. 58
} 
Apakah masih relevan manusia mempelajari teologi? Bagaimana ruang kerja teologi dalam budaya khususnya Indonesia yang merupakan negara multi budaya? Pertanyaan-pertanyaan ini perlu untuk dijawab secara serius oleh para kaum teolog khususnya teolog-teolog Indonesia.

Keterbatasan yang dimiliki manusia seharusnya tidak menjadi alasan di mana teologi tidak perlu untuk dipelajari. Justru sebaliknya, ketika mempelajari teologi kita belajar bagaimana mengasihi Allah dan bagaimana mengasihi manusia. Sangat mustahil apabila kita mengaku mengasihi Allah dengan segenap hati kita lalu kita membenci sesama kita hanya karena sebuah perbedaan. Alkitab secara gamblang mengatakan dua poin inti dari keseluruhan hukum taurat, yakni kasihilah Tuhan Allahmu dengan segenap hatimu, jiwamu dan akal budimu dan kasihilah sesamamu manusia seperti dirimu sendiri. (Matius 22: 37-40). Keterbatasan mengenal Allah secara sempurna membuat manusia membutuhkan iman. Sebagaimana yang dikatakan oleh Muriwali Yanto Matalu dalam karya dogmatika kristennya bahwa teologi adalah sebuah pembelajaran dari Tuhan melalui Alkitab dan wahyu umum. Pembelajaran tersebut mutlak didahului oleh iman, karena tanpa iman teologi menjadi mustahil. ${ }^{10}$ Iman mendahului kita dalam mempelajari teologi. Teologi tidak boleh terlepas dari iman. Apabila iman dilepaskan dari teologi maka, sama halnya dengan kita berusaha mengarungi samudera yang begitu luas tanpa menggunakan kompas.

Berteologi di tengah keberagaman membuat kita berusaha untuk mencari metode yang tepat. Sebuah metode yang dapat menjadikan teologi sebagai ilmu yang mudah diajarkan dan dapat diterima oleh kalangan setempat tanpa harus mencabut atau menghilangkan budaya yang ada. Lalu berteologi seperti apa yang bisa ditawarkan? Teologi konstektual dalam hal ini dapat dipakai untuk pemberitaan Injil dengan menggunakan kearifan lokal yang berkembang dalam daerah tersebut. Sama hal yang dikerjakan oleh Eben N. Timo dalam bukunya yang berjudul "Meng-Hari-Ini-Kan Injil di Bumi Pancasila", Eben berusaha agar supaya setiap dogmatika yang berkembang di Indonesia, entah Calvinisme, Lutheran, Baptis, dan lain-lain, bisa diterima oleh masyarakat Pancasila ${ }^{11}$ tanpa

\footnotetext{
${ }^{10}$ Muriwali Yanto Matalu, Dogmatika Kristen Dari Perspektif Reformed, (Malang: 2017), hal. 63.

${ }^{11}$ Ada 4 sistem berpikir dalam kita memandang Pancasila, yakni Pancasila sebagai dasar negara, Pancasila sebagai pandangan atau falsafah hidup bangsa, Pancasila sebagai substansi perekat bangsa dan pancasila sebagai ideologi. Lihat Andreas Doweng, et.al, Pancasila Kekuatan Pembebas, (Yogyakarta: 2012), hal. 28-32. Namun demikian dengan memandang Pancasila sebagai sebuah ideologi, bukan berarti bahwa Pancasila mencabut akan identitas seseorang atau kelompok karena dijadikan sebagai dasar negara. Melainkan jika kita melihat lebih dalam isi dari pada Pancasila maka kita akan menemukan bahwa Pancasila berusaha untuk menyatukan keberagaman ideologi yang ada, dalam satu ideologi, yakni Pancasila. Untuk hal ini, akan dibahas lebih lanjut.
} 
mendiskreditkan budaya yang begitu kaya yang dimiliki oleh bangsa Indonesia. Berteologi selalu identik dengan dogma yang diajarkan. Oleh karena itu, Eben N. Timo memberikan fungsi dari dogmatika: ${ }^{12}$

1. Menyediakan penalaran dan penjelasan terhadap dogma-dogma secara akademis, sistematis, dan koheren kepada warga gereja yang dapat dipakai sebagai senjata bagi gereja untuk membela diri terhadap bahaya atau ancaman dari berbagai ajaran sesat yang berpotensi mengaburkan atau menghancurkan identitas gereja.

2. Memperlengkapi gereja dengan berbagai instrumen untuk menimbang, menilai, dan menguji kehidupan dan pemberitaan agar sesuai dengan firman Allah dan relevan dengan realitas kehidupan praktis Gereja masa kini.

Kedua fungsi ini tidak boleh terpisah saat kita berteologi. Begitu banyaknya ajaran sesat yang marak berkembang saat-saat ini, menuntut kita untuk berusaha menyusun dogmatika yang sistematis dan sesuai dengan kebenaran Firman Tuhan. Selain itu, dogmatika yang diajarkan sebisa mungkin menjadi relevan dalam kehidupan praktis. Selanjutnya, Eben N. Timo memberikan penjelasan bahwa

Dalam konteks masyarakat yang dikondisikan oleh kemiskinan, penindasan, korupsi dam kekerasan, kita harus menemukan makna dari sapaan atau gelar-gelar bagi Allah, yang memampukan manusia masa kini tidak kehilangan arah dalam usahanya membenahi dunia dan masyarakat, demi keadilan dan kesejahteraan semua komponen masyarakat. ${ }^{13}$

Selanjutnya, bagaimana dengan budaya? Saya tahu hal ini begitu riskan apabila kita berusaha mengawinkan teologi dengan budaya. Akan ada beberapa teolog konservatif dan juga beberapa kaum injili yang tidak setuju apabila teologi Kristen diintegrasikan dengan budaya. Bagi mereka, budaya adalah berhala karena menyembah kepada dewa-dewa yang dipercayai oleh masyarakat suku. Namun, seperti yang saya katakan di atas bahwa apabila teologi atau ideologi atau agama mencabut budaya dalam diri seseorang atau komunitas, maka sama halnya dengan berusaha mencabut identitas seseorang/ komunitas.

Sebelum agama Kristen masuk di Indonesia, masyarakat Indonesia telah memiliki kepercayaan yang disebut dengan agama suku. Dengan demikian, sebelum kekristenan masuk di Indonesia melalui para misionaris pada masa penjajahan, masyarakat telah memiliki

\footnotetext{
${ }^{12}$ Ebenhaize Nuban Timo, Allah Menahan Diri Tapi Pantang Berdia Diri Suatu Upaya Berdogmatika Kontekstual di Indonesia, (Jakarta: 2016), hal. 18

${ }^{13}$ Ibid. hal. 54
} 
kepercayaan kepada yang Ilahi. Masyarakat Indonesia saat itu telah sadar akan adanya kuasa adikodrati yang mereka yakini sebagai dewa yang berkuasa atas diri dan komunitas mereka. Salah satu contohnya, tradisi pesta ulat sagu di suku Kombai dan Korowai Papua. Tradisi ini dilakukan oleh suku tersebut agar dewa tidak mengirimkan bencana yang dapat mengancam kehidupan mereka dan hasil tanaman dapat memiliki hasil yang baik. ${ }^{14}$ Hal ini menunjukkan bahwa masyarakat suku, menaruh kehidupan mereka pada dewa yang meraka yakini memiliki kekuatan yang dapat memusnahkan kehidupan. Dengan kata lain, ada kekuatan supernatural yang melampaui kekuatan manusia pada umumnya yang dipercayai oleh suku tersebut.

Selanjutnya bagaimana ruang gerak teologi dalam berbangsa dan bernegara? Negara Indonesia memiliki dasar negara yang terdiri dari lima prinsip/ sila yang kita sebut dengan Pancasila. Dasar negara ini menjadi identitas seluruh warga negara. "Ketuhanan Yang Maha Esa" pada sila pertama memiliki pengertian bahwa setiap warga negara berhak atas kepercayaan/ agama yang dipeluknya dan hak tersebut merupakan hak mutlak. Frans Magnis Suseno mengatakan bahwa:

"Ketuhanan Yang Maha Esa" menetapkan bahwa orang dari segala bentuk Ketuhanan sepenuhnya warga bangsa dan bahwa agama mayoritas - suatu kebesaran hati istimewa - tidak menuntut kedudukan khusus dalam undang-undang dasar Indonesia. Sekaligus kebebasan beragama dan hormat terhadap keyakinan religius segenap warga dinyatakan menjadi prinsip dasar kenegaraan republik. ${ }^{15}$

Melihat hal ini, dapat kita sebut bahwa kebebasan beragama merupakan hak dari seluruh masyarakat Indonesia tanpa adanya intimidasi dari pihak luar yang berusaha untuk mengancam akan eksistensi seseorang dalam berbangsa dan bernegara. Kebebasan beragama bukan hanya berlaku pada 6 (enam) agama yang diakui oleh negara yakni Kristen, Katolik, Islam, Hindu, Buddha dan Kong $\mathrm{Hu} \mathrm{Cu}$, melainkan agama-agama suku yang menjadi kepercayaan masyarakat suku pun berhak untuk dipeluk dan pemeluk agama suku pun patut untuk mendapat perlindungan yang sama. Selanjutnya pada tulisan yang lain, Romo Magnis mengatakan bahwa agama tidak boleh mengancam. Agama harus baik kepada semua orang. Artinya agama harus baik/ terbuka kepada yang orang yang seiman maupun yang tidak seiman, karena mereka pun diciptakan dan dicintai oleh Allah. ${ }^{16}$

\footnotetext{
${ }^{14}$ Henk Venema, Hidup Baru Orang Kristen Dalam Konteks Kebudayaan Setempat, (Jakarta:2006)

${ }^{15}$ John Campbell-Nelson, et.al (Ed), Op. cit. hal. 142.

${ }^{16}$ Frans Magnis Susena, et.al, Agama, Keterbukaan dan Demokrasi Harapan dan Tantangan, (Jakarta: 2015), hal. 6-7.
} 
Dalam hubungannya dengan teologi, cara kita berbangsa dan bernegara merupakan bagian dari cara kita berteologi. Teologi tidak hanya melulu berbicara mengenai bagaimana membangun hubungan dengan Tuhan dalam hal berdoa dan tanpa melakukan apa pun. Beribadah dan tanpa melalukan apa pun atau pun mengurung diri sehingga dunia tidak mencemari kita. Sebaliknya, Yesus menjawab pertanyaan Petrus yang bertanya kemana Tuhan akan pergi dengan berkata bahwa "Ke tempat Aku pergi, engkau tidak dapat mengikuti Aku sekarang, tetapi kelak engkau akan mengikuti aku (Yoh. 13:36)". Apa maksudnya? Dalam pesan terakhir Yesus, Ia mengingatkan murid-murid-Nya tidak hanya memiliki hubungan yang intim dengan Allah, melainkan juga mengasihi sesama (Yoh. 15:17). Setelah Yesus mengatakan kepada murid-murid-Nya untuk mengasihi sesama, Ia berkata kepada mereka apa yang akan mereka alami setelah Ia naik ke Sorga, yakni akan ada banyak orang yang tidak menyukai mereka. Mereka akan disiksa, dianiaya, dimusuhi oleh karena kepercayaan mereka kepada-Nya. Namun tugas mereka bukan untuk membalas, melainkan terus mengasihi sesama. Mengasihi sesama tidak akan pernah terlepas dari kita turut ambil bagian dalam berbangsa dan bernegara.

Tanggung-jawab semua warga negara merupakan ikut ambil bagian dalam pembangunan ke arah kemajuan bangsa dan negara. Ikut ambil bagian dalam hal ini bisa berupa mendukung setiap program-program yang disusun oleh pemerintah guna membangung bangsa dan negara. Tidak hanya itu saja, menaati setiap peraturan yang dikeluarkan oleh pemerintah karena kita tahu bersama bahwa, pemerintah yang memerintah adalah bagian dari rencana Allah dalam suatu negara. Salah satu aturan yang dibuat oleh negara untuk ditaati oleh semua masyarakatnya adalah HAM (Hak Asasi Manusia).

Berhubungan dengan Hak Asasi Manusia di mana setiap manusia berhak atas hidupnya, setiap manusia berhak atas agamanya, setiap manusia berhak atas kepercayaan, maka menghargai orang yang memiliki kepercayaan yang berbeda merupakan bagian dari pada kita berbangsa dan bernegara dan juga wujud dari pada dasar negara yang kita cintai, yakni Pancasila. Hal ini dilakukan agar supaya wujud dari sila kelima dari Pancasila, yakni "Keadilan sosial bagi seluruh rakyat Indonesia" dapat terwujud. Sama seperti yang dikatakan oleh Magnis sebelumnya bahwa kaum mayoritas tidak mendapat perlakuan khusus tetapi baik kaum mayoritas maupun minoritas mendapat perlakuan yang sama oleh negara. Oleh karena itu, Banggalah dengan Indonesia. Banggalah dengan kebhinekaan Indonesia yang disatukan dalam satu dasar negara, yakni PANCASILA! 


\section{Kearifan Lokal Sebagai Pendekatan Aplikatif dalam Berteologi dan Berbudaya}

Kearifan lokal terdiri dari dua kata yang berbeda. Kearifan/ wisdom merupakan suatu sifat yang melekat pada diri manusia sehingga membuatnya menjadi arif dan bijaksana. Selanjutnya lokal/ local merupakan kondisi suatu tempat atau wilayah tertentu. ${ }^{17}$ Selanjutnya, menurut UU No 32 Tahun 2009 memberikan pengertian bahwa kearifan lokal merupakan nilai-nilai luhur yang berlaku di dalam tata kehidupan masyarakat yang bertujuan untuk melindungi sekaligus mengelola lingkungan hidup secara lestari. Armada Riyanto juga memberikan definisi kearifan lokal sebagai filsafat yang hidup di dalam hati masyarakat, berupa kebijaksanaan akan kehidupan, way of life, ritus-ritus, adat dan sejenisnya. ${ }^{18}$ Berdasarkan definisi-definisi di atas, maka kearifan lokal (local wisdom) bisa diartikan sebagai sifat arif/ bijaksana dari seseorang atau suatu kelompok yang berkembang pada suatu tempat atau wilayah tertentu sebagai cara hidup yang berhubungan dengan budaya atau kepercayaan di suatu daerah tertentu. Tentunya sifat arif/ bijaksana pada suatu tempat atau wilayah berbeda dengan sifat arif/ bijaksana pada tempat atau daerah lain (locus). Hal inilah yang menjadi karakter daripada kearifan lokal. ${ }^{19}$

Selanjutnya, kearifan lokal tentu tidak akan pernah lepas dari pada bahasa, kebiasaan (budaya), agama, cerita-cerita rakyat, sumber daya alam (SDA) dan lain sebagainya. Kearifan lokal selalu menjadi senjata yang mumpuni untuk dapat mempersatukan masyarakat sekalipun berbeda kepercayaan, agama, bahkan ideology apa pun. Inilah yang dilakukan oleh Don Richardson dalam pelayanannya untuk memberitakan Injil di suku Sawi tanah Papua di mana selalu terjadi perang antar suku dan hal ini menimbulkan keresahan dalam hidupnya. Akhirnya, ia menemukan satu kearifan lokal yang berlaku di dalam masyarakat suku Sawi bahwa seorang anak dapat menjadi perjanjian perdamaian.

Kearifan lokal yang dimiliki suatu daerah menjadi senjata yang jitu agar supaya kedamaian bisa terjaga dengan stabil. Kearifan lokal dalam suatu budaya merupakan hasil dari kepercayaan agama suku setempat. Namun dalam perjalanannya, kearifan lokal makin kehilangan makna karena terdegradasi oleh berbagai hal, salah satunya padangan teologis. Berbagai dogma dimunculkan dan makin menghilangkan identitas kearifan lokal. Hal ini

\footnotetext{
${ }^{17}$ Ahmad Baedowi, Calak Edu 4 Esai-Esai Pendidikan 2012-2014, (Jakarta: 2015), hal. 61

${ }^{18}$ Armada Riyanto, et. al (Ed). Kearifan Lokal-Pancasila Butir-Butir Filsafat Keindonesiaan, (Yogyakarta: 2015), hal. 28.

${ }^{19}$ Ibid, hal. 29
} 
membuat Juan Frank Hamah Sagrim memberikan warning melalui bukunya agar sebuah dogma tidak mendiskreditkan kepercayaan/agama suku. Berikut apa yang dikatakannya

"Baiklah kita berhati-hati mengenal akan agama-agama yang ada, jangan sampai karena dogmatika sebuah agama tertentu mendeskritkan kita sehingga membenci agama-agama-agama lain. Sebenarnya kita saling mengenal setiap agama itu dan inti sebuah agama yang baik akan dilihat dari perlakuan penganutnya, dilihat dari buahnya, dan hasilnya, diketahui mutu dan nilainya. Pengertian yang salah tentang Allah akan segera merusak agama yang menganut pengertian itu. Jalan kehidupan yang panjang dari bangsa Israel dengan jelas menyatakan hal ini dan sejarah gereja menguatkan pernyataan itu". ${ }^{20}$

Senada dengan itu, Daniel K. Listijabudi dalam karyanya yang diberi judul Bergulat di Tepian, memberikan sumbangan yang besar dalam menggunakan teks-teks yang menjadi kearifan lokal sebuah budaya. Kisah Dewa Ruci diintegrasikan secara apik dengan kisah pergulatan Yakub bersama Malaikat Tuhan. ${ }^{21}$ Selain itu, Daniel K. Listijabudi juga menggunakan cerita-cerita mistik yang dikawinkan dengan teks kisah pergulatan Yakub di tepi Sungai Yabok.

Dari hal ini bisa dilihat bahwa berteologi dan berbudaya merupakan dua unsur yang tidak bisa dipisahkan satu dengan yang lainnya. Menilai sebuah budaya harusnya dinilai dari kaca mata orang lokal sendiri yang tidak dipengaruhi oleh pra-konsep akan keburukan budaya tersebut. Sayangnya, Konsep moderen yang berkembang selalu mendiskreditkan budaya. Tak jarang kita mendengar orang sering berkata "ah hari gini masih percaya yang gitu-gituan". Mereka tidak sadar bahwa mereka dilahirkan atau berasal dari masyarakat suku yang percaya "gitu-gituan". Selain itu, dengan mengatakan "ah hari gini masih percaya yang gitu-gituan" secara tidak sadar dia sendiri sedang mendiskreditkan identitasnya atau dengan kata lain sedang memusnahkan identitasnya. Dari sini dapat diketahui bahwa segala sesuatu yang berhubungan dengan kebudayaan, entah itu cerita mistik, simbol-simbol, ritual-ritual menunjukkan bahwa nenek moyang kita telah menyadari akan adanya suatu kuasa adikodrati yang lebih besar. Kuasa adikodrati tersebut juga dipercaya dapat memberikan bencana, kutuk atau juga berkat, kesuburan dan kedamaian. Menjadi Indonesia berarti menjadi masyarakat berbudaya. Menjadi orang Kristen berarti menjadi pengikut Kristus yang berbudaya. Teologi dan budaya tidak boleh saling membunuh satu dengan yang lain. Namun sebaliknya, setiap

\footnotetext{
${ }^{20}$ Juan Frank Hamah Sagrim, History of God Tribals Religion (Kisah Tuhan Dalam Agama Suku) Rahasia Theologia Tradisional Suku Maybrat Imian Sawiat Papua Wiyon-Wofle Diparalelkan Dengan Alkitab, (Yogyakarta: 2010), hal. 62

${ }^{21}$ Daniel K. Listijabudi, Bergulat di Tepian Pembacaan Lintas Tekstual Dua Kisah Misktik (Dewa Ruci \& Yakub di Yabok) Untuk Membangun Perdamaian), (Jakarta: 2019).
} 
lubang kosong yang ada pada budaya, dapat diisi dengan teologi misalnya menjelaskan siapa dewa yang mereka sembah, siapa yang berkuasa atas alam semesta yang berkuasa untuk mendatangkan kesuburan dan bencana. Selanjutnya karena budaya merupakan identitas, maka tentunya masyarakat telah terikat dengan budaya mereka sehingga berteologi dengan tidak menghilangkan identitas, merupakan sebuah keharusan.

\section{Pela Gandong, Siapa Sesamaku? ( Sebuah Jembatan yang Menyatukan)}

Dalam kehidupan orang Indonesia seperti yang dikatakan oleh Retnowati, suku bangsa adalah sebuah ide, kenyataan dan ideologi yang tidak bisa ditawar-tawar ataupun dibendung. ${ }^{22}$ Tidak ada satu hal pun yang dapat membendung satu ide khas yang berkembang pada satu daerah tertentu. Misalnya kearifan lokal yang berkembang di daerah Ambon yakni pela gandong.

Kehidupan masyarakat Ambon, hidup dalam keberagaman namun hal tersebut tidak membuat orang lain menjadi musuh oleh karena berbeda agama, ideologi dan kepercayaan. Sebaliknya, Islam dan Kristen sebelum konflik selalu hidup berdampingan. Persaudaraan begitu terasa. Orang Kristen membantu pembangunan masjid sebaliknya juga demikian, orang Islam membantu pembangunan gereja. Hal ini bisa terjadi oleh karena ada satu kepercayaan yang dipercayai oleh masyarakat Ambon, yakni Pela gandong ${ }^{23}$.

Pela gandong merupakan ciri khas orang Ambon di mana meskipun hidup dalam perbedaan ideologi maupun agama namun persaudaraan terikat kuat. Hal inilah yang ditemukan oleh Prof. Sumanto Al Qurtubi dalam penelitiannya mengenai pasca-konflik dan pendamaian Islam-Kristen di Ambon. Salah satu yang mendukung terjadinya perdamaian ialah kearifan lokal yang dimiliki masyarakat Ambon yakni pela gandon. Dikatakan bahwa saat konflik komunal terjadi ada sejumlah tokoh agama lokal baik dari Islam maupun dari Kristen yang bukan menggemakan perang melainkan justru menyerukan perdamaian. ${ }^{24}$

Kearifan lokal yang dimiliki oleh suatu daerah tidak pernah lepas dari agama suku yang berkembang di dalam daerah tersebut. Oleh karena itu ada sembilan poin yang diusulkan oleh Prof. Sumanto untuk menghindari konflik yang bisa kembali terjadi dan salah

${ }^{22}$ Izak Lattu. et.al (Ed).Op.Cit. hal. 88

${ }^{23}$ Pela gandong berasal dua suku kata yang memiliki arti. Pela berarti adanya suatu ikatan persatuan yang begitu erat, sedangkan gandong merupakan saudara.Jadi secara sederhana pela gandong berarti ikatan persatuan dalam persaudaraan.

${ }^{24}$ Sumanto Al Qurtubi, Islam-Kristen Dinamika Pascakonflik dan Masa Depan Perdamaian di Ambon, (Jakarta: 2018). 98-99 
satu dari kesimbilan usulan tersebut adalah memelihara kearifan lokal. Kesembilan poin tersebut adalah: ${ }^{25}$

1. Kelompok/ para aktor yang membuat Maluku sengsara harus diusut dan diproses secara tegas di pengadilan.

2. Karena Front Kedaulatan Maluku (FKM) adalah sebuah bentuk perjuangan moralintelektual, pemerintah harus membebaskan aktivis FKM yang ditahan dan merehabilitasi name-nama para narapidana. Status narapidana yang disematkan kepada aktivis FKM yang dipenjara juga harus dihapus.

3. Percepatan pembangunan di Maluku untuk membebaskan rakyat dari kemiskinan.

4. Pemerintah-pusat maupun daerah - perlu mendorong masyarakat membentuk forum-forum dialog yang melibatkan semua komponen elemen, baik kelompok moderat maupun konservatif agama, untuk membangun kembali Maluku yang terkoyak selama konflik.

5. Perlu ada upaya "rekonsiliasi plus" bukan "rekonsialiasi minus".

6. Perlu ada scholarship/ bantuan studi kepada anak-anak korban konflik kerusuhan.

7. Pemerintah perlu menciptakan lapangan-lapangan pekerjaan baru karena konflik menyebabkan orang kehilangan pekerjaan.

8. Pemerintah perlu menganjurkan warganya, khususnya para pengungsi, agar kembali ke daerah asal seperti sebelum kerusuhan, atau hidup membaur bersama kelompok agama lain.

9. Perlu menjaga dan melestarikan nilai-nilai luhur budaya lokal yang sudah diajarkan oleh para datuk terdahulu (seperti pela gandong, masohi, familian, dsb).

Akhirnya, "jang cuma tagal beda agama, kepercayaan, ideologi katong jadi bakalae”. Alangkah baiknya jika istilah ini terus dikumandangkan dan selalu diingatkan kepada generasi-generasi selanjutnya untuk terus menjaga persaudaraan sehingga kedamaian hidup rukun satu dengan yang lain dalam perbedaaan dengan menggunakan kearifan lokal (local wisdom) yakni "Pela Gandong" terus lestari.

\section{Allah di Tengah-tengah Kemajemukkan}

Manusia dikatakan Alkitab diciptakan "serupa" dan "segambar" dengan Allah (Kej. 1:26). Apa maksud dari pada "segambar" dan "serupa" dengan Allah? Dalam teks Ibrani

\footnotetext{
${ }^{25}$ Ibid. hal. $119-123$
} 
ditulis "betsalmenu kidemutnu". Kata pertama berasal dari kata tselem dan kata kedua berasal dari demut. Terjemahan harafiah dari frasa ini adalah "menurut gambar kita", "mengikuti rupa kita" ${ }^{26}$ Berdasarkan pengertian dari akar kata yang digunakan dalam teks bahasa Ibrani, siapa yang menjadi serupa dan segambar dengan Allah? Adalah naif jika dengan berani mengatakan bahwa hanya orang Kristen yang diciptakan serupa dan segambar dengan Allah sedangkan orang yang beragama lain, tidak diciptakan serupa dan segambar dengan Allah. Tidak ada tentunya dengan berani mengatakan bahwa orang yang beragama di luar agama Kristen, tidak diciptakan serupa dan segambar dengan Allah. Jika demikian, Allah yang Maha-Kuasa menciptakan manusia yang berbeda-beda menjadi serupa dan segambar denganNya, maka bagaimana dengan manusia sendiri? Andar Ismail selanjutnya mengatakan:

Allah yang tunggal membuat ciptaan yang berbeda-berbeda, dan yang berbeda-beda itu dicintai-Nya secara sama. Allah yang tunggal, namun "gambar dan rupa"-Nya plural. Allah tunggal, namun Ia mencitrakan diri-Nya dalam bermacam-macam ragam. Allah memang tunggal namun Ia bineka. ${ }^{27}$

Dalam buku Andreas A. Yewangoe menjelaskan topik tentang the case for God: Allah dalam masyarakat majemuk Indonesia mengatakan bahwa baik Islam maupun Kristen memakai nama yang sama, yaitu "Allah", guna mengacu kepada sesembahan mereka. ${ }^{28}$ Pertanyaan yang sama seperti yang dilontarkan oleh A.A. Yewangoe dalam bukunya mengatakan bahwa apakah Allah yang sama disembah oleh kaum Islam dan Kristen? Berdasarkan karya Juan Cole sebagaimana yang dikutip oleh Yewangoe untuk meneliti akar kata yang dipakai dalam teks-teks bahasa Semitik menarik kesimpulan al-illah adalah Elohim, sebab kedua nama tersebut berakar dari akar kata yang sama dan tokoh-tokoh yang ditulis baik dalam Alquran dan Alkitab merupakan tokoh yang sama. ${ }^{29}$ Hasil penelitian Cole menjadi menarik apabila diterapkan pada kita bangsa Indonesia. Allah yang sama yang disembah oleh masyarakat Islam dan Allah yang sama pula yang disembah oleh masyarakat Kristen dan bahkan Allah yang sama yang disembah oleh masyarakat suku sehingga Allah yang mencintai keanekaragam hadir dalam masyarakat yang beranegakaragam, berkuasa bukan hanya pada kedua agama yang besar di Indonesia, yakni Islam-Kristen, melainkan semua agama baik yang diakui oleh negara maupun agama-agama suku yang ada di Indonesia. Baik yang mayoritas maupun yang minoritas. Kita satu dalam kesatuan.

\footnotetext{
${ }^{26}$ Andar Ismail, Op.cit. hal. 90.

${ }^{27}$ Ibid, hal. 93.

${ }^{28}$ A.A. Yewangoe, Allah Mengizinkan Manusia Mengalami Diri-Nya, (Jakarta: 2018), hal. 12

${ }^{29}$ Ibid. hal. 13-15.
} 


\section{Kesimpulan}

Kekayaan yang dimiliki oleh Indonesia tidak hanya berupa sumber daya alam yang begitu melimpah melainkan juga budaya, bahasa, simbol, ritual dan lain sebagainya menjadikan Indonesia negara yang unik bila dibandingkan dengan negara-negara lainnya. Keunikan ini menjadi hal yang patut untuk disyukuri. Kearifan lokal yang dimiliki oleh Indonesia pun beragam. Satu daerah memiliki kearifan lokal yang berbeda satu dengan yang lainnya. Kearifan lokal dalam hal cerita-cerita mistik, budaya, simbol dan ritual-ritual lainnya menjadikan Indonesia negara yang banyak diminati oleh bangsa lain.

Teologi, agama, ideologi dan kepercayaan lainnya seharus tidak boleh saling memusnahkan. Indonesia lahir dari keanegaraman yang bila ditelusuri dalam sejarah, ini merupakan perjuangan para pahlawan yang tidak mengenal lelah untuk memperjuangkan kemerdekaan. Saat pembuatan isi Pancasila dalam sila pertama KeTuhanan Yang Maha Esa menjadikan identitas bangsa Indonesia yang akan selalu dipakai. Menghilangkan sila pertama merupakan menghilangkan identitas bangsa Indonesia. Apa jadinya apabila identitas sebuah bangsa dihilangkan? Jadi apabila ada orang yang berdasarkan teologi, agama, ideologi dan kepercayaan kemudian ini memusnahkan kebinekaan, maka sebaiknya dia atau mereka keluar dari Indonesia dan bentuk negara sendiri, di mana mereka bisa menerapkan ideologi mereka.

Teologi Kristen pun demikian. Berteologi seharusnya tidak menganggap budaya merupakan hal najis atau penyembahan berhala yang harus ditinggalkan.Berteologi seharus memperhatikan dogmatika yang digunakan sehingga tidak menghilangkan budaya. Berteologi dengan menggunakan kearifan lokal merupakan salah satu cara kita melestarikan budaya dengan Injil. Injil dapat disampaikan melalui budaya.Tidak hanya itu, Injil dapat diterima dengan sukacita tidak hanya oleh kalangan kaum moderen melainkan juga oleh orang-orang yang kental dengan budaya.

Dasar negara Indonesia adalah Pancasila. Pancasila merupakan identitas dari masyarakat Indonesia. Dengan kata lain, orang mengenal bahwa Indonesia adalah negara pluralistik yang terdiri dari berbagai macam kepercayaan/ agama hal ini dapat dilihat dalam sila pertama dalam Pancasila, yakni "KeTuhanan Yang Maha Esa”. Selain itu, kemanusiaan yang adil dan beradab, persatuan Indonesia, Kerakyatan yang dipimpin oleh hikmat kebijaksanaan dalam permusyawaratan perwakilan dan selanjutnya negara mengusahakan agar terjadinya keadilan sosial bagi seluruh rakyat Indonesia. Apa yang akan terjadi bila identitas bangsa Indonesia, yakni Pancasila dicabut? Tentu sama seperti yang dikatakan oleh 
C.S. Song bahwa identitas merupakan hakekat dari seseorang, maka apabila identitas Indonesia dicabut, sama halnya dengan mencabut akan hakekat bangsa Indonesia.

Akhirnya, banggalah menjadi Indonesia. Banggalah dalam kebhinekaan. Banggalah terhadap PANCASILA sebagai dasar negara kesatuan Indonesia!*** 


\section{DAFTAR PUSTAKA}

Baedowi Ahmad. 2015. Calak Edu 4 Esai-Esai Pendidikan 2012-2014. Jakarta: Alvabeta

Darmaputera Eka. 2017. Pancasila Identitas \& Modernitas. Jakarta: BPK Gunung Mulia.

Doweng Andreas, et.al. 2012. Pancasila Sebagai Kekuatan Pembebas, Yogyakarta: Kanisius

Drewes.B.F. dan Mojau Julianus. 2012. Apa Itu Teologi? Pengantar ke Dalam Ilmu

Teologi.Jakarta: BPK Gunung Mulia

Ismail Andar. 2019. Selamat Mengindonesia, Jakarta: BPK Gunung Mulia

Lattu Izak, et. al. (Ed). 2016. Sosiologi Agama Pilihan Berteologi di Indonesia. Salatiga: UKSW.

Listijabudi.K Daniel. 2019. Bergulat di Tepian Pembacaan Lintas Tekstual Dua Kisah Mistik (Dewa Ruci \& Yakub di Yabok) Untuk Membangun Perdamaian. Jakarta: BPK Gunung Mulia.

Matalu Yanto Muriwali. 2017. Dogmatika Kristen Dari Perspektif Reformed. Malang: GKKR

Riyanto Armada, et. al. (Ed). 2015. Kearifan Lokal-Pancasila Butir-butir Berfilsafat Keindonesiaan. Yogyakarta: Kanisius

Suseno Magnis Frans, et.al. 2015. Agama, Keterbukaan dan Demokrasi Harapan dan Tantangan. Jakarta: Pusat Studi Agama dan Demokrasi (PUSAD).

Nelson-Campbell John, et.al. (Ed). 2013. Teologi Politik Panggilan Gereja di Bidang Politik Pascaorde Baru. Makasar: OASE INTIM

Timo I. Nuban Ebenhaizer. 2016. Allah Menahan Diri, Tetapi Pantang Berdiam Diri Suatu Upaya Berdogmatika Kontekstual di Indonesia. Jakarta: BPK Gunung Mulia

Sagrim Frank Hamah Juan. 2010. History Of God In Tribals Religion. Yogyakarta: CV MAJAV

Song C.S. 2001. Sebutkanlah Nama-Name Kami Teologi Cerita Dari Perspektif Asia.Jakarta: BPK Gunung Mulia

Venema Henk. 2006. Hidup Baru Orang Kristen Dalam Konteks Kebudayaan Setempat.Jakarta: YKBK

Yewangoe A.A. 2018. Allah Mengizinkan Manusia Mengalami Diri-Nya. Jakarta: BPK Gunung Mulia. 